\title{
Pembuatan Produk UMKM Bergizi Melalui Pelabelan dan Diversifikasi Produk Pelaku UMKM, Kelurahan Cipedak, Jakarta Selatan
}

\section{Khoirul Anwar*1, Almira Nuraelah², Hamidatun ${ }^{3}$, Winda Zahraningrum4 ${ }^{4}$, Syafiqa Suhaila $^{5}$}

\author{
1,2,4,5Program Studi Gizi, Fakultas Teknologi Pangan dan Kesehatan, Universitas Sahid, Indonesia \\ ${ }^{3}$ Program Studi Teknologi Pangan, Fakultas Teknologi Pangan dan Kesehatan, Universitas Sahid, Indonesia \\ *e-mail: khoirul_anwar@usahid.ac.id ${ }^{1}$
}

\begin{abstract}
Abstrak
UMKM (Usaha Mikro Kecil dan Menengah) memiliki peran penting terhadap perkenomian Indonesia. Mitra UMKM kegiatan pengabdian masyarakat ini adalah pelaku UMKM Kelurahan Cipedak, Jakarta Selatan yang bergerak dalam pengolahan produk makanan dan minuman. Kegiatan ini bertujuan untuk meningkatkan pengetahuan dan kemampuan mitra dalam pembuatan produk UMKM yang lebih bergizi. Kegiatan dilaksanakan di lokasi mitra di Kelurahan Cipedak, Jagakarsa, Jakarta Selatan. Kegiatan terdiri dari beberapa tahapan sebagai berikut: 1) Identifikasi kebutuhan mitra UMKM, 2) Review materi sesuai dengan kebutuhan mitra, 3) Pembuatan materi edukasi, 4) Kegiatan Edukasi, 5) Praktik Pembuatan Produk, dan 6) Evaluasi Pengetahuan, Sikap dan Kebermanfaatan Program. Berdasarkan kegiatan yang dilaksanakan diperoleh beberapa manfaat untuk mitra diantaranya adalah meningkatnya pengetahuan tentang label dan produk UMKM bergizi, meningkatnya sikap mitra tentang label dan produk UMKM bergizi serta meningkatnya kemampuan mitra dalam pembuatan produk UMKM bergizi. Variasi produk UMKM yang dihasilkan memberikan peluang lebih besar kepada mitra untuk meningkatkan pendapatan mitra. Sehubungan dengan beragam manfaat dari kegiatan ini, mitra meminta tim pengabdian masyarakat agar kegiatan dalam dilanjutkan kembali. Selain itu, berdasarkan evaluasi kebermanfaat program, Sebagian besar peserta (>90\%) menyatakan bahwa kegiatan ini bermanfaat dan perlu dilanjutkan.
\end{abstract}

Kata kunci: Edukasi, Gizi, Label Pangan, UMKM

\begin{abstract}
UMKM (Usaha Mikro Kecil dan Menengah) have an important role in the Indonesian economy. The UMKM partners of this community service activity are UMKM actors in Cipedak Village, South Jakarta which are engaged in processing food and beverage products. This activity aims to increase the knowledge and capabilities of partners in making more nutritious UMKM products. The activity was carried out at partner locations in Cipedak Village, Jagakarsa, South Jakarta. The activity consists of several stages as follows: 1) Identification of the needs of UMKM partners, 2) Review of materials according to partner needs, 3) Creation of educational materials, 4) Educational Activities, 5) Product Manufacturing Practices, and 6) Evaluation of Knowledge, Attitudes and Benefit Program. Based on the activities carried out, several benefits were obtained for partners including increasing knowledge about labels and nutritious UMKM products, increasing partner attitudes about nutritious UMKM labels and products and increasing partner capabilities in manufacturing nutritious UMKM products. The variety of UMKM products produced provides partners with greater opportunities to increase partner income. In connection with the various benefits of this activity, the partners asked the community service team to resume the activities. In addition, based on the evaluation of the usefulness of the program, most of the participants (>90\%) stated that this activity was useful and needed to be continued.
\end{abstract}

Keywords: Education, Food Labels, Nutrition, UMKM

\section{PENDAHULUAN}

\subsection{Analisis Situasi}

Mitra Pengabdian kepada Masyarakat ini adalah pelaku UMKM CV. Ain Elghur yang bergerak dalam pengolahan produk makanan dan minuman yang berlokasi di Jl. Muamalah 1 No. 56 RT 01/03 Kelurahan Cipedak, Kec Jagakarsa, Jakarta Selatan. Mitra UMKM memulai memproduksi pangan olahan yang banyak diminati oleh masyarakat, antara lain pempek dan 
beragam jenis minuman botanikal cair. Karyawan pada umkm tersebut berjumlah kurang lebih 10 orang. Pemasaran mitra UMKM meliputi area Jakarta dan beberapa pesanan dari luar kota Jakarta. UMKM (Usaha Mikro Kecil dan Menengah) merupakan sebuah bisnis yang dilakukan secara individu, rumah tangga, atau badan usaha ukuran kecil. UMKM digolongkan berdasarkan beberapa indikator, yaitu omzet per tahun, jumlah kekayaan atau aset, serta jumlah karyawan (Undang-Undang Republik Indonesia Nomor 20 Tahun, 2008). Saat ini, UMKM merupakan salah satu aspek penting dalam perekonomian di Indonesia (Hamza, 2019; Niode, 2019; Putra, 2018; Sofyan, 2017). Penggolongan UMKM dalam sektor ekonomi dibagi menjadi sembilan yaitu 1) Pertanian, Peternakan, Kehutanan dan Perikanan; 2) Pertambangan dan Penggalian; 3) Industri Pengolahan; 4) Listrik, Gas dan Air Bersih; 5) Bangunan; 6) Perdagangan, Hotel dan Restoran; 7) Pengangkutan dan Komunikasi; 8) Keuangan, Persewaan dan Jasa Perusahaan, dan 9) Jasa-jasa (Sarwono, 2015; Yazfinedi, 2018).

Pandemi Covid-19 memiliki dampak terhadap UMKM yang berpengaruh kepada pendapatan pelaku masyarakat (Bahtiar, 2021; Hamanay et al., 2021; Silfia \& Utami, 2021). Saat ini, telah disusun tiga pilar dalam pemberdayaan UMKM. Pada setiap pilar kebijakan pemberdayaan UMKM, disusun strategi berupa rencana aksi yang akan dilaksanakan untuk mencapai tujuan. Terdapat enam strategi yang disusun, antara lain: 1) Perluasan akses pasar, 2) Peningkatan daya saing, 3) Pengembangan kewirausahaan, 4) Akselerasi pembiayaan dan investasi, 5) Kemudahan dan kesempatan berusaha, 6) Koordinasi lintas sektor (Tim Kebijakan Peningkatan Kapasitas Ekonomi Sekretariat TNP2K Indonesia, 2020). Berbagai riset menunjukkan bahwa pelatihan dan bimbingan yang diberikan kepada pelaku UMKM dapat memberikan dampak positif pada peningkatan pengetahuan, sikap dan keterampilan pelaku UMKM (Lestari Nasution et al., 2021; Raharja \& Natari, 2021). Beberapa pelatihan yang dapat dilakukan untuk UMKM adalah melalui pengembangan modifikasi produk melalui penambahan bahan sumber zat gizi tertentu (Hubeis et al., 2015; Tim Kebijakan Peningkatan Kapasitas Ekonomi Sekretariat TNP2K Indonesia, 2020) dan pelatihan tentang pelabelan produk UMKM untuk meningkatkan kualitas kemasan produk sehingga diharapkan daoat meningkatkan minat konsumen (Herydiansyah, 2019; Irrubai, 2015; Yuliani \& Widyakanti, 2020).

Berdasarkan uraian di atas, maka permasalahan yang dihadapi mitra adalah: 1) Belum adanya diversifikasi produk dengan kandungan gizi yang lebih beragam, 2) Belum adanya penerapan tentang pelabelan pangan bergizi UMKM, 3) Belum memiliki pengetahuan tentang pelabelan pangan yang bergizi, dan 4) Adanya keinginan pelaku UMUM untuk mengembangkan produk UMKM yang memiliki kandungan gizi yang lebih beragam

\subsection{Solusi dan Target}

Berdasarkan permasalahan yang dihadapi oleh mitra, solusi yang diberikan adalah: 1) pemberian edukasi kepada mitra tentang produk UMKM yang bergizi sesuai dengan Pedoman Gizi Seimbang, 2) Pemberian edukasi kepada mitra tentang pelabelan produk UMKM yang bergizi, dan 3) Peningkatan kemampuan mitra dalam pembuatan produk UMKM dengan kandungan gizi yang lebih beragam.

\section{METODE}

\subsection{Tempat dan Waktu}

Kegiatan dilaksanakan di lokasi mitra yaitu UMKM CV. Ain Elghur yang bergerak dalam pengolahan produk makanan dan minuman yang berlokasi di Jl. Muamalah 1 No. 56 RT 01/03 Kelurahan Cipedak, Kec Jagakarsa, Jakarta Selatan. Kegiatan dilaksanakan pada bulan Desember 2021.Sasaran kegiatan pengabdian masyarakat ini adalah pelaku UMKM di Kelurahan Cipedak, Kec Jagakarsa, Jakarta Selatan.

\subsection{Metode Kegiatan Edukasi dan Praktik}

Kegiatan edukasi yang diberikan kepada mitra UMKM adalah edukasi tentang regulasi 
label pangan sesuai dengan aturan yang berlaku, edukasi tentang pencantuman nilai gizi pada label produk UMKM dan edukasi tentang produk UMKM bergizi sesuai dengan Pedoman Gizi Seimbang (PGS) dan Isi Piringku. Pembuatan materi edukasi dilakukan dengan tahapan sebagai berikut: 1) Identifikasi kebutuhan mitra UMKM, 2) Review materi sesuai dengan kebutuhan mitra, 3) Pembuatan materi edukasi (Gambar 1). Materi edukasi yang dibuat dibagi menjadi tiga topik yaitu Topik 1: Regulasi Label Pangan, Topik 2: Pentingnya label Gizi untuk Produk UMKM, dan Topik 3: Produk UMKM Bergizi sesuai Gizi Seimbang dan Isi Piringku; 4) Kegiatan Edukasi, 5) Praktik Pembuatan Produk, dan 6) Evaluasi Pengetahuan, Sikap dan Kebermanfaatan Program.

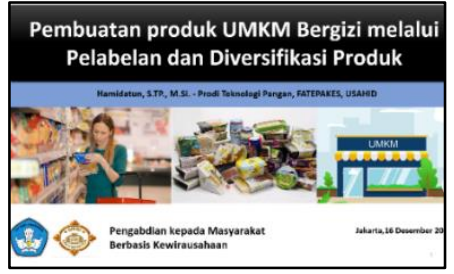

(a)

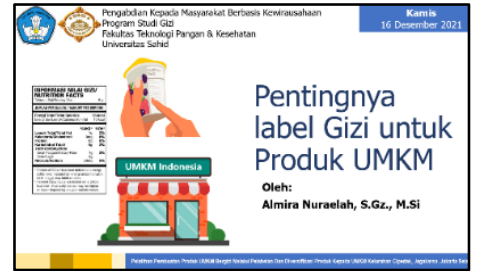

(b)

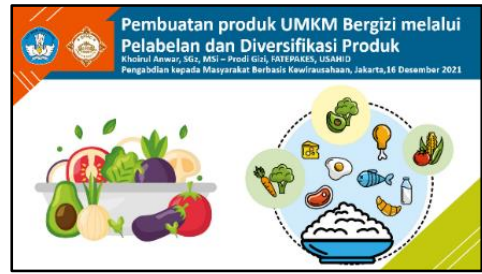

(c)

Gambar 1. Materi edukasi gizi (a) regulasi label pangan (b) pentingnya label gizi (3) pembuatan produk UMKM bergizi

Kegiatan edukasi dilakukan dengan metode partisipasi aktif yang melibatkan mitra dalam diskusi. Edukasi diberikan dengan menggunakan bahan materi yang sudah disusun dan dilanjutkan dengan sesi diskusi tentang materi yang diberikan dan sharing tentang apa yang sudah dilakukan oleh mitra terkait dengan topik yang diberikan oleh tim PKM.

Dalam rangka meningkatkan kemampuan mitra UMKM dalam hal pengembangan produk UMKM bergizi, dilakukan praktik secara langsung tentang pembuatan produk UMKM bergizi melalui modifikasi bahan dengan menambahkan aneka sayuran ke produk UMKM dengan produk Pempek. Penambahan aneka jenis sayuran ini diharapkan dapat meningkatkan kandungan serat dan vitamin pada produk Pempek yang sebelumnya rendah kandungan serat dan vitamin tersebiut. Selain itu, penambahan sayuran diharapkan dapat memberikan warna yang menarik dan meningkatkan penerimaan terhadap produk.

\subsection{Metode Evaluasi Pengetahuan, Sikap dan Kebermanfaatan Program}

Evaluasi pengetahuan, sikap dan kebermanfaatan program dilakukan dengan menggunakan kuesioner yang diberikan kepada mitra. Kuesioner meliputi pengetahuan, sikap sebelum dan setelah edukasi dan praktik tentang kegiatan yang diberikan. Selain itu, evaluasi kebermanfaatan program juga diberikan dengan menggunakan kuesioner yang diberikan kepada mitra yang dilengkapi dengan video testimoni kegiatan.

\section{HASIL DAN PEMBAHASAN}

\subsection{Pelaksanaan Kegiatan Edukasi}

Kegiatan pengabdian masyarakat terdiri dari edukasi, praktik pembuatan produk UMKM bergizi, evaluasi pengetahuan dan sikap serta kuesioner kepuasan. Mitra terdiri dari 10 orang dengan latar belakang pelaku umkm industri makanan dan minuman. Beberapa produk pangan olahan yang diproduksi oleh mitra ialah pempek dan minuman botanikal cair (kunyit asem, bir pletok, beras kencur dan temulawak). di Kelurahan Cipedak, Kec. Jagakarsa, Jakarta Selatan. Materi pertama dengan topik "Label Pangan Olahan" terkait fungsi label pangan dan cara pencantuman informasi pada label pangan sesuai dengan peraturan perundang-undangan khususnya peraturan BPOM No. 31 tahun 2018 tentang label pangan olahan. Mitra diharapkan mampu memahami informasi apa saja yang minimal harus dicantumkan dan informasi apa saja yang dilarang dicantumkan dalam label pangan sehingga mitra mampu membuat design label pangan yang tidak hanya menarik namun juga sesuai dengan aturan perundang-undangan. 
Materi kedua dengan topik "Pentingnya label gizi untuk produk UMKM" dijelaskan tentang cara membaca informasi nilai gizi dan pembuatan format informasi nilai gizi pada label pangan sesuai dengan peraturan BPOM No. 16 tahun 2019 tentang label pangan olahan untuk UMKM. Selanjutnya diberikan materi tentang "Pembuatan produk UMKM bergizi" yang dijelaskan tentang pembuatan produk UMKM yang bergizi melalui modifikasi bahan untuk meningkatkan kandungan gizi, warna dan aroma. Modifikasi produk UMKM dapat dilakukan melalui subtitusi dan penambahan bahan berupa aneka jenis sayuran yang merupakan sumber serat dan dapat meningkatkan variasi warna dari produk yang UMKM mitra. Kegiatan dilanjutkan dengan sesi diskusi dan tanya jawab terkait dengan topik edukasi yang diberikan. Dokumentasi pelaksanaan kegiatan edukasi kepada mitra dapat dilihat pada Gambar 2.
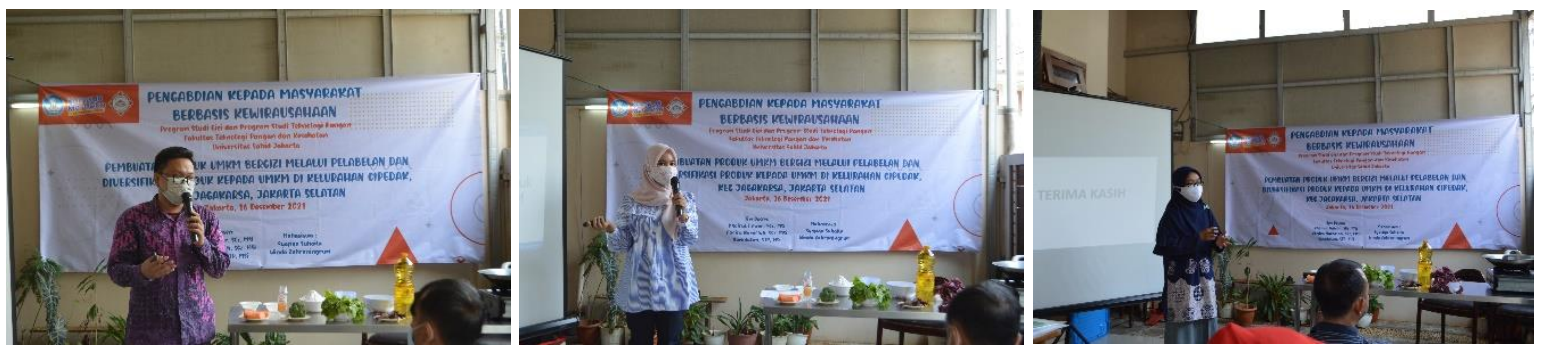

Gambar 2. Pelaksanaan Kegiatan Edukasi kepada Mitra

\subsection{Pelaksanaan Praktik Pembuatan Produk}

Praktik diversifikasi produk mitra UMKM yang dilakukan pada kegiatan ini adalah produk pempek mitra. Kegiatan ini dilakukan dengan penambahan sayur dan ekstrak sayur ke dalam resep pempek original. Pada kegiatan ini, peserta diajak untuk praktik secara langsung di tempat untuk membuat produk pempek sayur (Gambar 3). Praktik pembuatan produk terdiri dari 1) persiapan bahan, 2) pembentukan pempek bentuk lenjer, isi telur dan adaan dengan penambahan ekstrak sayuran, dan 3) perebusan produk pempek. Pempek dengan bahan dasar sekitar 35-37\% ikan tenggiri dan 35-37\% tapioka mengandung protein hewani dan karbohidrat. Penambahan sayuran pada pempek terdiri dari ekstrak sayur untuk subtitusi bahan baku air $(17 \%)$ dan sayuran yang dicincang (6.4\%) bertujuan untuk menambah kandungan serat, vitamin dan mineral pada produk pempek. Berbagai riset menunjukkan bahwa sayuran memiliki banyak kandungan gizi terutama serat, vitamin dan zat aktif yang bermanfaat untuk kesehatan (Dias, 2012; GórskaWarsewicz et al., 2021).

Sayuran yang ditambahkan ialah bayam merah, bit, bayam hijau, brokoli dan wortel. Ekstrak sayur dari buah bit, wortel dan bayam hijau memiliki warna khas merah, oranye dan hijau sehingga mampu membuat pempek menjadi berwarna dan lebih menarik. Warna khas sayuran tersebut berasal dari golongan senyawa flavonoid, betakaroten dan klorofil yang memiliki fungsi sebagai antioksidan (Andarwulan et al., 2010; Hayet et al., 2021). Pempek merah terdiri dari dari tambahan sayur bayam merah dan ekstrak buah bit, pempek hijau terdiri dari tambahan sayur brokoli dan ekstrak bayam hijau, serta pempek oranye terdiri dari tambahan sayur dan ekstrak sayur wortel. Produk pempek pelangi diharapkan dapat menjadi alternatif pilihan makanan yang enak dan bergizi.
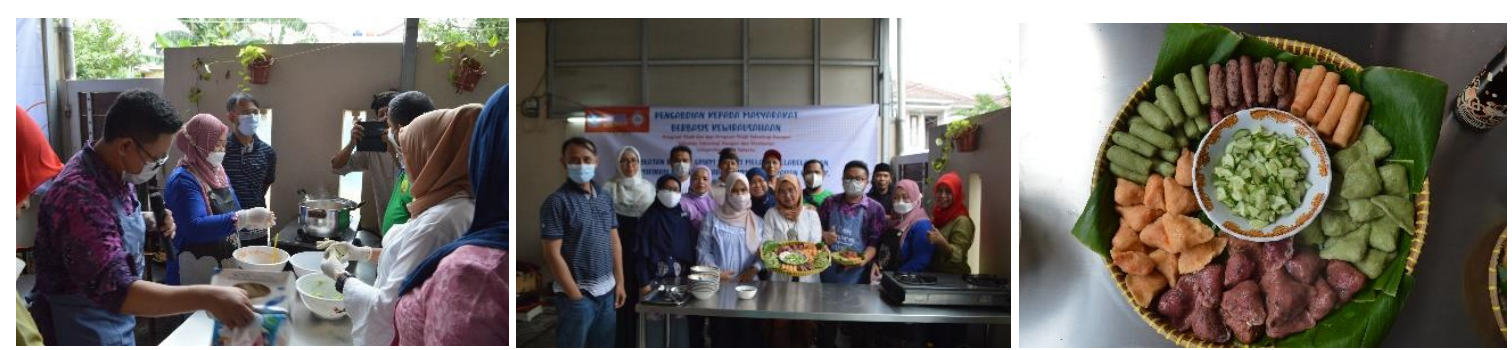

Gambar 3. Pelaksanaan praktik pembuatan produk modifikasi UMKM 


\subsection{Fungsi dan Manfaat Hasil Penelitian dan Pengabdian Masyarakat}

Kegiatan ini memiliki fungsi dan manfaat dalam peningkatan pengetahuan dan praktik mitra UMKM tentang label produk UMKM bergizi dan tentang pembuatan produk UMKM yang diperkaya dengan kandungan gizi seperti serat dan vitamin. Selain itu, dapat meningkatkan pengetahuan dan sikap UMKM terhadap modifikasi produk UMKM yang bergizi. Berdasarkan hasil kuesioner pre-posttest pengetahuan dan sikap mitra tentang topik yang diberikan (Gambar 4), diperoleh hasil bahwa terjadi peningkatan dalam pengetahuan dan sikap mitra. Pengetahuan mitra meningkat dari skor awal 56 menjadi 69.09 (skor maksimal 100), dan sikap mitra meningkat dari skor awal 99.3 menjadi 100 (skor maksimal 100). Hal ini menunjukkan bahwa kegiatan ini memiliki manfaat yang positif terhadap mitra pelaku UMKM. Mitra UMKM setuju untuk mengembangkan produk UMKM yang bergizi menjadi salah satu produk mereka.

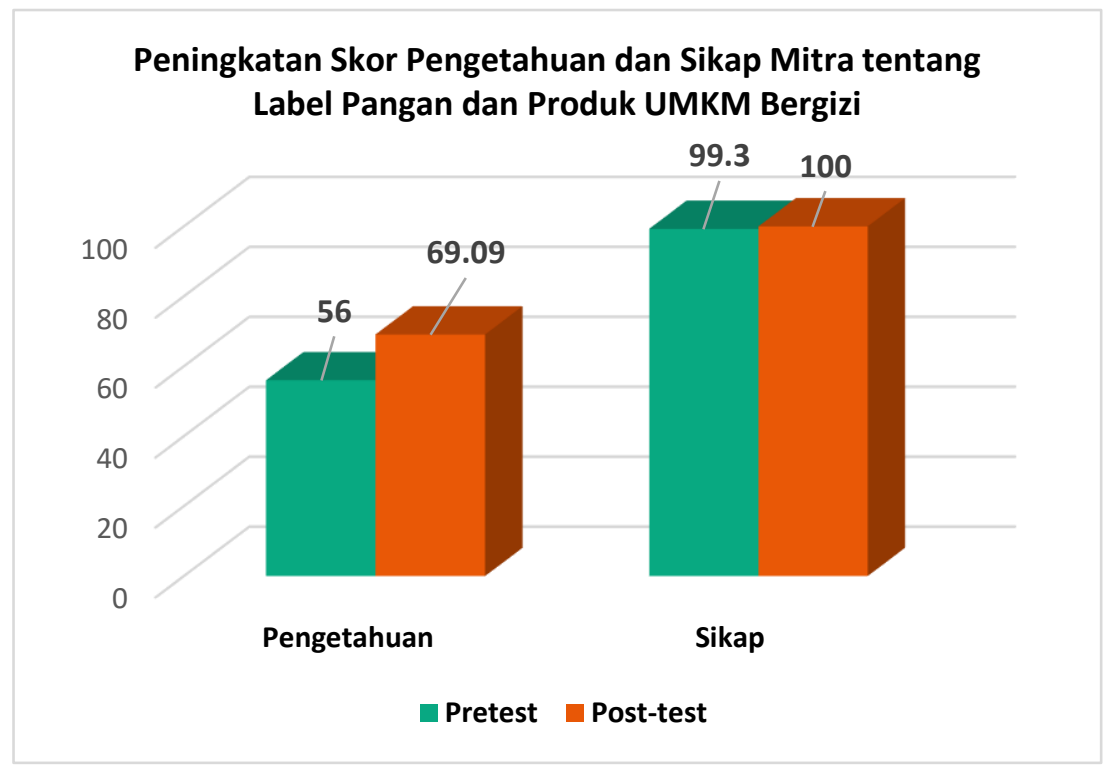

Gambar 4. Hasil skor pre-post test pengetahuan dan sikap mitra

\subsection{Evaluasi Kebermanfaatan Program}

Berdasarkan hasil kuesioner evaluasi kebermanfaatan program (Tabel 1) diketahui sebesar $54,55 \%$ peserta memberikan penilaian sangat setuju bahwa program pengabdian masyarakat yang dilakukan ini sesuai dengan kebutuhan mitra. Materi pelatihan yang diberikan tergolong pengetahuan dan keterampilan baru bagi mitra terkait aturan pelabelan produk pangan dan diversifikasi produk pangan pempek dengan penambahan sayuran. Hal ini ditunjukkan dengan data sebesar $72,73 \%$ peserta menyatakan sangat setuju adanya peningkatan pengetahuan pembuatan produk UMKM bergizi dan pengetahuan pelabelan produk pangan UMKM. Selain itu, $63,63 \%$ peserta menyatakan setuju bahwa terjadi peningkatan pengetahuan mengenai informasi nilai gizi.

Mitra pelaku UMKM dalam kegiatan ini sangat antusias terhadap jenis kegiatan pengabdian masyarakat yang dikembangkan. Hal ini ditunjukkan dari data sebesar $63,64 \%$ peserta menyatakan sangat setuju terkait setiap pertanyaan yang diajukan peserta ditindaklanjuti dengan baik oleh narasumber/anggota yang terlibat dan sebesar $63,64 \%$ peserta menyatakan merasa puas dengan kegiatan pengabdian masyarakat ini. Antusiasme mitra yang tinggi menunjukkan kegiatan ini berpotensi untuk dilakukan kembali dalam rangka pengembangan produk UMKM yang memiliki nilai jual lebih. Hal ini didukung pula oleh pernyataan mitra bahwa kegiatan ini perlu dilanjutkan kembali sesuai dengan kebutuhan mitra sehingga mitra UMKM dapat lebih berkembang. Secara keseluruhan, mitra UMKM sangat setuju bahwa kegiatan pengabdian masyarakat yang dilakukan bermanfaat terhadap mitra. 
Tabel 1. Hasil evaluasi kebermanfaatan kegiatan pengabdian masyarakat

\begin{tabular}{|c|c|c|c|c|c|}
\hline \multirow[t]{2}{*}{ No } & \multirow[t]{2}{*}{ Evaluasi } & \multicolumn{4}{|c|}{ Kriteria penilaian* } \\
\hline & & 4 & 3 & 2 & 1 \\
\hline 1 & $\begin{array}{l}\text { Program Pengabdian masyarakat Universitas } \\
\text { Sahid dilaksanakan sesuai dengan kebutuhan } \\
\text { UMKM }\end{array}$ & $54.55 \%$ & $36.36 \%$ & $0.00 \%$ & $9.09 \%$ \\
\hline 2 & $\begin{array}{l}\text { Program Pengabdian masyarakat Universitas } \\
\text { Sahid telah memberikan bekal kepada UMKM } \\
\text { berupa keterampilan berpikir ataupun } \\
\text { keterampilan lainnya }\end{array}$ & $54.55 \%$ & $45.45 \%$ & $0.00 \%$ & $0.00 \%$ \\
\hline 3 & $\begin{array}{l}\text { Pelaksanaan kegiatan telah mampu meningkatkan } \\
\text { pengetahuan mengenai pembuatan produk } \\
\text { UMKM bergizi }\end{array}$ & $72.73 \%$ & $27.27 \%$ & $0.00 \%$ & $0.00 \%$ \\
\hline 4 & $\begin{array}{l}\text { Pelaksanaan kegiatan telah mampu meningkatkan } \\
\text { pengetahuan mengenai pelabelan produk UMKM }\end{array}$ & $72.73 \%$ & $27.27 \%$ & $0.00 \%$ & $0.00 \%$ \\
\hline 5 & $\begin{array}{l}\text { Pelaksanaan kegiatan telah mampu meningkatkan } \\
\text { pengetahuan mengenai informasi nilai gizi }\end{array}$ & $63.64 \%$ & $36.36 \%$ & $0.00 \%$ & $0.00 \%$ \\
\hline 6 & $\begin{array}{l}\text { Anggota yang terlibat dalam kegiatan pengabdian } \\
\text { masyarakat Universitas Sahid telah melaksanakan } \\
\text { sosialisai kepada UMKM atas program yang } \\
\text { disampaikan }\end{array}$ & $54.55 \%$ & $45.45 \%$ & $0.00 \%$ & $0.00 \%$ \\
\hline 7 & $\begin{array}{l}\text { Tim pengabdian masyarakat Universitas Sahid } \\
\text { sangat kompak dalam melaksanakan program } \\
\text { sesuai dengan keilmuan masing-masing }\end{array}$ & $72.73 \%$ & $27.27 \%$ & $0.00 \%$ & $0.00 \%$ \\
\hline 8 & $\begin{array}{l}\text { Setiap pertanyaan yang saya ajukan di } \\
\text { tindaklanjuti dengan baik } \\
\begin{array}{lll}\text { narasumber/anggota yang terlibat } & \text { oleh }\end{array}\end{array}$ & $63.64 \%$ & $36.36 \%$ & $0.00 \%$ & $0.00 \%$ \\
\hline 9 & $\begin{array}{l}\text { Program pengabdian masyarakat Universitas } \\
\text { Sahid dilaksanakan dengan sarana dan prasarana } \\
\text { yang sesuai }\end{array}$ & $54.55 \%$ & $45.45 \%$ & $0.00 \%$ & $0.00 \%$ \\
\hline 10 & $\begin{array}{l}\text { Saya merasa puas dengan kegiatan pengabdian } \\
\text { masyarakat yang diselenggarakan oleh Fakultas } \\
\text { Teknologi Pangan Dan Kesehatan, Universitas } \\
\text { Sahid }\end{array}$ & $63.64 \%$ & $36.36 \%$ & $0.00 \%$ & $0.00 \%$ \\
\hline
\end{tabular}

* Keterangan :

4 : Sangat Setuju

3 : Setuju

2 : Tidak Setuju

1 : Sangat Tidak Setuju

\section{KESIMPULAN}

Kegiatan pengabdian masyarakat Pembuatan Produk UMKM Bergizi Melalui Pelabelan dan Diversifikasi Produk Kepada UMKM di Kelurahan Cipedak, Kec Jagakarsa, Jakarta Selatan bermanfaat untuk mitra yang ditandai dengan adanya peningkatan pengetahuan mitra, sikap mitra yang setuju untuk melaksanakan hasil dari kegiatan, dan juga evaluasi kebermanfaatan program yang diminta untuk dilanjutkan kembali.

\section{UCAPAN TERIMA KASIH}

Terimakasih kepada LPPM Universitas Sahid dan kepada mitra kegiatan pengabdian masyarakat ini. 


\section{DAFTAR PUSTAKA}

Andarwulan, N., Batari, R., Sandrasari, D. A., Bolling, B., \& Wijaya, H. (2010). Flavonoid content and antioxidant activity of vegetables from Indonesia. Food Chemistry, 121(4), 1231-1235. https://doi.org/10.1016/j.foodchem.2010.01.033

Bahtiar, R. A. (2021). Dampak Pandemi Covid-19 Terhadap Sektor Usaha Mikro, Kecil, dan Menengah Serta Solusinya. Pusat Penelitian Badan Keahlian DPR RI, Bidang Ekonomi Dan Kebijakan Publik, XIII(10), 19-24. https://berkas.dpr.go.id/puslit/files/info_singkat/Info Singkat-XIII-10-II-P3DI-Mei-2021-1982.pdf

Dias, J. S. (2012). Nutritional Quality and Health Benefits of Vegetables: A Review. Food and Nutrition Sciences, 03(10), 1354-1374. https://doi.org/10.4236/fns.2012.310179

Górska-Warsewicz, H., Rejman, K., Kaczorowska, J., \& Laskowski, W. (2021). Vegetables, potatoes and their products as sources of energy and nutrients to the average diet in poland. International Journal of Environmental Research and Public Health, 18(6), 1-23. https://doi.org/10.3390/ijerph18063217

Hamanay, N. D., Ekasari, L. U. H. D., \& Mukoffi, A. (2021). Dampak Covid-19 Terhadap Pendapatan UMKM Pada Pabrik Usaha Tahu Amda. Akuntansi Kompetif, 7.

Hamza, L. M. (2019). Effect of Micro, Small and Medium Enterprises Development on National Income in the MSME Sector in Indonesia. Jurnal Ekonomi Pmbangunan, 8(2), 215-228. http://jurnal.feb.unila.ac.id/index.php/jep/article/view/45

Hayet, S., Sujan, K. M., Mustari, A., \& Miah, M. A. (2021). Hemato-biochemical profile of turkey birds selected from Sherpur district of Bangladesh. Int. J. Adv. Res. Biol. Sci, 8(6), 1-5. https://doi.org/10.22192/ijarbs

Herydiansyah, G. (2019). Penyuluhan Pentingnya Label Pada Kemasan Produk Dan Pajak Pada Usaha Kecil Menengah (Ukm) Desa Tebedak Ii Kecamatan Payaraman Ogan Ilir. Jurnal Ilmiah Pengabdian Kepada Masyarakat, 53(9), 1689-1699.

Hubeis, M., Purwanto, B., Dewi, F. R., Widyastuti, H., \& Febtyanisa, M. (2015). Developing Strategies ofCompetitive-Food Small Medium Enterprises in Indonesia. Prosiding Seminar Hasil-Hasil PPM, I(1), 126-143.

Irrubai, M. L. (2015). Strategi Labeling, Packaging dan Marketing Produk Hasil Industri Rumah Tangga Di Kelurahan Monjok Kecamatan Selaparang Kota Mataram Nusa Tenggara Barat. Society, 6(1), 15-30.

Lestari Nasution, W. S., Nusa, P., \& Putra, S. D. (2021). Membangkitkan Umkm Di Tengah Pandemi Covid 19. TRIDHARMADIMAS: Jurnal Pengabdian Kepada Masyarakat Jayakarta, 1(1), 9. https://doi.org/10.52362/tridharmadimas.v1i1.494

Niode, I. Y. (2019). Sektor umkm di Indonesia: profil, masalah dan strategi pemberdayaan. Jurnal Kajian Ekonomi Dan Bisnis OIKOS-NOMOS, 2(1), 1-10. https://repository.ung.ac.id/kategori/show/uncategorized/9446/jurnal-sektor-umkm-diindonesia-profil-masalah-dan-strategi-pemberdayaan.html

Putra, A. H. (2018). Peran Umkm Dalam Pembangunan Dan Kesejahteraan Masyarakat Kabupaten Blora. Jurnal Analisa Sosiologi, 5(2). https://doi.org/10.20961/jas.v5i2.18162

Raharja, S. J., \& Natari, S. U. (2021). Pengembangan Usaha Umkm Di Masa Pandemi Melalui Optimalisasi Penggunaan Dan Pengelolaan Media Digital. Kumawula: Jurnal Pengabdian Kepada Masyarakat, 4(1), 108. https://doi.org/10.24198/kumawula.v4i1.32361

Sarwono, H. A. (2015). Profil Bisnis Usaha Mikro, Kecil Dan Menengah (Umkm). Bank Indonesia Dan LPPI, 1-135.

Silfia, B., \& Utami, A. (2021). Dampak Pandemi Covid 19 Terhadap Sektor UMKM di Indonesia. 03(1), $1-7$.

Sofyan, S. (2017). Peran UMKM dalam Perekonomian Indonesia. Jurnal Bilancia, 11(1), 33-59. https://jurnal.iainpalu.ac.id/index.php/blc/article/view/298/216 
Tim Kebijakan Peningkatan Kapasitas Ekonomi Sekretariat TNP2K Indonesia. (2020). Pemetaan Program Pemberdayaan Usaha Mikro, Kecil, dan Menengah (UMKM). http://tnp2k.go.id/download/62816Buku_Pemetaan Program Pemberdayaan Usaha Mikro, Kecil, dan Menengah (UMKM).pdf

Undang-Undang Republik Indonesia Nomor 20 Tahun. (2008). Undang-Undang Republik Indonesia Nomor 20 Tahun 2008. 1.

Yazfinedi. (2018). Usaha mikro, kecil, dan menengah di indonesia: permasalahan dan solusinya. Jurnal Ilmiah Kesejahteraan Sosial, XIV, 33-41.

Yuliani, R., \& Widyakanti, W. (2020). Peningkatan Penjualan Melalui Inovasi Kemasan dan Label Pada UMKM. Jurnal Keuangan Umum Dan Akuntansi Terapan, 2(2), 71-76. http://jurnal.pknstan.ac.id/index.php/KUAT/article/view/990 